\title{
Exploration on the Transformation Path of Financing Platform Company under Risk Prevention
}

\author{
Minghao Li \\ Anhui University of Finance and Economics, China
}

442097777@qq.com

\begin{abstract}
The financing platform, as the hidden borrowing subject of local government, plays an important role in the process of local economic construction. However, this kind of borrowing mode not only has the concealment, but also has the characteristics of blind expansion and even raffish borrowing, which makes the hidden debt of local government become the most important link in preventing systemic financial risk currently. In such an environment, the marketization transformation of financing platform companies is more urgent and meaningful. If the platform companies can keep a foothold in the market independently of the government, the significance of alleviating the debt risk of local governments is self-evident. By analyzing the current situation of the existing urban construction \& investment company, combining the national policy background and referring to the previous successful transformation cases of the urban construction \& investment company, this paper proposes the possible path of the marketization transformation of the urban construction \& investment company in view of the existing difficulties in the transformation of the urban construction \& investment company. However, the transformation of urban construction \& investment company faces many difficulties, which require the joint efforts of central government, local government and enterprise.
\end{abstract}

Keywords: Urban construction \& investment company Local government debt, Marketization transformation, Debt risk.

\section{Introduction}

Since the reform of the national tax distribution system in 1994, local governments have "transferred financial power and retained administrative power", but the burden of basic economic construction undertaken by local governments has not decreased while tax revenue has declined. At the same time, since the budget law of 1995 clearly stipulated that the local governments could not issue government bond, local governments fell into the dilemma of the mismatch between "financial power" and "administrative power". In order to raise funds more conveniently and promote the development of city investment, local financing platforms relying on the government came into being, and municipal bond gradually appeared all over China. With the help of the government and the high credit of the local government, the urban construction \& investment company has quickly gained the deep trust among people, and at the same time, with the advantage of cost and term, it has raised a large amount of funds for the investment and development of the city. Urban construction \& investment company also gradually developed in the whole country and became an important channel for local government financing.

However, while making a significant contribution to local economic development, the disadvantages of municipal bond and urban construction \& investment company have gradually emerged. The fund borrowed by urban construction \& investment company is mainly used for urban infrastructure projects or public welfare projects, which have the characteristics of long return cycle and low rate of return. On the other hand, the promotion of local officials in China is mainly based on GDP. To improve their performance, some local government officials try to finance as much as possible, or even borrow blindly or raffishly. Both of them directly affect the principal and interest repayment of municipal bond, aggravate financial risks and even affect the credit of local governments. For example, in August 2018, state-owned assets management co., ltd. of the sixth division of Xinjiang production and construction corps planned to conduct interest payment and encashment of the first phase of short-term financing bond of 2017 (17 corps six division SCP001) on August 13, 2018, but it still failed to pay the interest and make encashment on time until the end 
of the 13th. Although the interest payment and encashment was conducted in the later period and did not constitute a material default, it also reflects the risk of municipal bond to some extent.

In such a political and economic environment, the country has also gradually attached importance to the development of municipal bonds. The central government has taken a combination of measures to reduce the financial risks arising from municipal bond to a manageable level. Relevant laws and regulations have been issued successively to control the scale of municipal bond, promote the marketization transformation of urban construction \& investment company, and cut off the invisible relationship between the government and urban construction \& investment company. Under such a trend, if city investment corporation does not improve its profitability through transformation, it can only be weighed down by debt. Therefore, to resolve the local debt crisis, promoting the marketization transformation of urban construction \& investment company is the main way.

Although the central government continues to introduce measures, city investment corporation still faces many difficulties. First, under the pressure of preventing systemic financial risk, the time for transformation is pressing. Secondly, for local governments, there is still a strong reliance on financing platforms and a weak willingness to transform. Finally, as the profitability of urban construction \& investment company is generally low, the company has neither transformation ability nor transformation motivation. This paper mainly relies on the development history and current situation of urban construction \& investment company and municipal bond, combines the current attitude and measures of the central government and local government, and draws lessons from the previous successful transformation cases of urban construction \& investment company and proposes the following possible paths for the transformation of urban construction \& investment company. After clearing the platform of shell urban construction \& investment company, it can exit the market. The enterprises which are mainly based on infrastructure and have strong profitability can be integrated and reorganized into state-owned public welfare enterprises. A certain professional enterprise can expand the main business to achieve diversified development. The enterprise that has certain condition, can lay out finance to realize the integration of industry and finance. However, if the urban construction \& investment company is to be successfully transformed, it still needs the policy support of the central government, the fiscal support of the local government and the efforts of the urban construction \& investment company itself.

\section{The Current Situation of Municipal Bond and the Problems in Transformation}

\subsection{Ten Years of History and Current Situation of Municipal Bond}

\subsubsection{Prosperous Development Under the Stimulus of the Four-Trillion-yuan Plan}

Affected by the global financial crisis in 2008, China's economy (mainly export-oriented economy) has been greatly impacted. China's economic growth rate declined by 4 percentage points in the fourth quarter, and its exports have seen negative growth. In November 2008, the state council introduced stronger domestic demand measures to gradually form the package program to cope with the international financial crisis. Economic circles call it the $\$ 4$ trillion plan. In response to the national call, local governments have been vigorously developing the economy. In order to raise the funds needed for investment, local financing platforms have been expanding rapidly.

\subsubsection{Regulation Recovered Shortly after Relaxation Again}

In 2011, the CBRC and NDRC strengthened the supervision of local financing platforms and regulated the issuance threshold at the same time, leading to a depression in infrastructure investment and a decline in macroeconomic boom. In order to continue the construction of governmentsubsidized housing projects, the NDRC gradually relaxed its bond issuance requirements for local financing platforms. "Banning new construction" has gradually become "controlling new construction", local financing platforms have also ushered a short "second spring". Issuance of municipal bond alone rose to $\$ 1.2$ trillion, up $211 \%$ from 2011 , with the government tacitly approving of the urban construction \& investment company's expansion. 


\subsubsection{Another Downturn Under the "Closing Backdoor" by the Central Government}

Local governments borrowed too much in 2012, following the central government's deregulation of urban construction \& investment company. The central government faced the trade-offs, arguing that the main contradiction is the financial risk from excessive borrowing, and that risk prevention takes precedence over economic growth. Therefore, in 2014, the state council issued "the state council's opinion on strengthening the management of local government debt", or document no. 43, clarifying the responsibilities of the government and enterprises, and government debt can't be borrowed through enterprise. Meanwhile, in order to facilitate the central government's supervision of local government borrowing, the new budget law allows local governments to issue government debt, forming a situation of "opening the front door and closing the back door". However, due to the small limit of government debt and the strict approval, local governments still rely on urban construction \& investment company. Although the state regulation has been strengthened, the urban construction \& investment company has the situation of " old institutions die hard".

\subsubsection{National Risk Prevention and Deleveraging Force Transformation}

Since 2016, the state has gradually attached importance to preventing and resolving systemic financial risks. Especially after the 19th CPC national congress and the economic work conference at the end of 2017, the sate regards financial risk prevention as the top of the three major battle to build a moderately prosperous society in all respects. According to survey data from a number of Chinese institutions, the debt scale of local government financing platform is about 30 trillion to 50 trillion yuan. The bank for international settlements (BIS) argues that if the hidden debt of local government financing platforms is counted as Chinese government debt leverage, Chinese government debt actually reached a high level of around 65 percent of GDP in mid-2017. It can be seen that the negative impact of local financing platform is gradually emerging. The central government intends to resolve the debt risk of local government, but refuses to pay for the debt of local government. Urban construction \& investment company urgently needs to "find its way out".

\subsection{The Transformation Problems Faced by Municipal Bond}

\subsubsection{From the Perspective of Risk Prevention: Transformation Time is Tight and Task is Heavy}

Due to the lack of effective supervision of the financial system by various financing platforms and urban construction \& investment company, the type of financing, the use of funds and the size of financing are basically decided by local governments. Moreover, local governments usually do not consider the efficiency of capital utilization and repayment of capital when financing. This raffish borrowing which has extremely concealment further aggravates the country's systemic financial risk.

Therefore, in order to give full play to the macro-prudential management role of financial stability and development, continue to strengthen financial deleveraging and steadily promote physical deleveraging, the state council issued the no. 88 document of the general office of the state council in October 2016. No.88 Document clearly stipulates that the guarantee contract not issued by government debt, local government and its departments is invalid. Local government and its departments are not liable for its debt. It can be seen that it is urgent for urban construction \& investment company to get rid of government financing function and transform to enterprise.

\subsubsection{From the Perspective of Local Government, There is Still Dependence on Financing Platform and Insufficient Impetus for Transformation}

Since 1994, in order to solve the problem of central fiscal deficit, the central government has implemented the tax distribution system, thus resulting in the situation of financial power moving upward and administrative power being detained. As can be seen from the promotion of Chinese officials, GDP is the most intuitive indicator for measuring local officials' achievements. In order to develop the economy, local government officials can only rely on the urban construction \& investment company, financing platform and other institutions to solve the problem of insufficient capital for construction. From January to June 2018, a total of 1410.9 billion yuan of local government 
bond was issued nationwide. Among them, general bond was 1043.6 billion yuan, special bond was 367.3 billion yuan. According to the purpose, new bond was 332.9 billion yuan, and replacement bond or refinancing bond was 1078 billion yuan. But as the various risk problems of financing platform emerge in endlessly, the local government debt index expands. In order to further strengthen the control of financial system and prevent systemic financial crisis caused by local governments' blind borrowing, the new budget law is issued and stipulates that local governments could borrow a certain amount of legal debt. Although the new budget law has been implemented, its total borrowing limit is also very small. Compared with the local government borrowing limit through financing platforms, it is not worth mentioning. Therefore, the impact of the new budget law on local urban construction \& investment company is not significant. Local governments are still dependent on urban construction \& investment company to raise funds, so they have little incentive to transform the urban construction $\&$ investment company.

\subsubsection{From the Perspective of the Enterprise Itself, the Profitability is Generally Insufficient and the Transformation Ability is Deficient.}

The main business of urban construction \& investment company is mostly public welfare projects or quasi-public welfare projects, and these projects have the characteristics of long recycling cycle, low rate of return, and even some projects do not generate any profit themselves. As a result, the company's own cash flow cannot fully cover the principal and interest of the debt. In addition, as the urban construction \& investment company has always been backed up by governmental, it leads to its imperfect structure, irregular operation process and lack of management experience of a good management system. In addition, there are still illusions about the implicit guarantee of departmental urban construction \& investment company to local government, and the department urban construction \& investment company lacks both the impetus and the ability to transform.

\section{Possible Transformation Paths for Urban Construction \& Investment Company}

The above analyzed the urban construction \& investment company's various problems and potential risks. In order to reduce the debt burden of local governments, respond to the national policy requirements of risk prevention and deleveraging, and cut off the hidden relationship between local governments and urban construction \& investment company, we need to conduct a unified identification and systematic classification of urban construction $\&$ investment company, and make reasonable guess on the possible transformation paths of urban construction \& investment company according to the different categories of the company and the specific conditions of the region.

\subsection{After the Platform of Shell Urban Construction \&Investment Company is Cleaned, tt Exits the Market}

Based on the above, we can see that some urban construction \& investment companies have no profitability at all, and their survival depends entirely on the support of local government. If the transformation is marketized, it is very likely that the company will go bankrupt due to its inability to make profits. Therefore, this kind of urban construction \& investment company does not have the possibility and necessity of transformation, so it is recommended that it be dissolved or incorporated into local government.

\subsection{Enterprises that are Mainly Based on Infrastructure and Have Strong Profitability Can be Integrated and Reorganized into Public Welfare State-owned Enterprises}

The transformation purpose of urban construction \& investment company is to cut off the implicit guarantee relationship with local government and establish an independent operation mode of selffinancing. However, based on the historical mission of urban construction\& investment company, it has been engaged in the financing, construction and operation of government public welfare projects and quasi-public welfare projects for many years, and has relatively rich experience in infrastructure. 
Urban construction \& investment company should use this advantage reasonably. If the resources of several urban construction \& investment companies in a region are integrated and reorganized into a public welfare state-owned enterprise whose main business is infrastructure and has strong market competitiveness, the enterprise has strong operation ability and profitability, which can not only be responsible for its own profits and losses, but also inherit the debt of the original enterprise, ensure the sustainability of debt and reduce the debt burden of local government.

For example, Chongqing water group co., 1td. timely seized the important strategic opportunity of comprehensively deepening reform in China, and made use of its own production and management experience to promote water construction and service purchase in Chongqing. Through state-owned equity transfer, it realizes its own transformation actively. On the evening of March 23, Chongqing water (601158) released its 2017 annual report, achieving business revenue of 4.471 billion yuan, up 0.40 percent from the same period last year. Net profit attributable to the owner of the parent company was 2.066 billion yuan, up 93.51 percent from the same period last year and earnings per share was 0.43 yuan. Net profit excluding non-recurring profit and loss was 1.91 billion yuan, and a cash bonus of 3 yuan (tax included) was proposed for every 10 shares. The successful transformation of Chongqing water group provides valuable practical experience for the transformation of urban construction \& investment company.

\subsection{A Certain Professional Enterprise Can Expand Its Main Business to Achieve Diversified Development}

For the marketization operational state-owned enterprises with relevant qualifications and strong expertise, the main business scope can be expanded on the basis of the original business, other business sectors can be created and diversified to enhance the hemopoietic ability, so as to divest the function of financing for local governments and gradually transform into general enterprises. For example, Ma 'anshan urban construction \& investment company, was restructured into Jiangdong holding, formally became a common enterprise. At this point, China's first innovation and reform work of local urban investment and financing platform was formally broken. Since then, , Ma 'anshan urban construction \& investment company and the local government has drawn a clear line, the government no longer makes implicit guarantee for enterprises, enterprises no longer borrow funds for the government, and their original debt is temporarily suspended. Through this separation between government and enterprises, the financing platform has improved its competitiveness, achieved its own standard and efficient operation, and its profitability has been constantly enhanced.

\subsection{The Enterprise with a Certain Condition, Can Lay Out Finance to Realize the Integration of Industry and Finance}

The 19th CPC national congress proposed to deepen the reform of state-owned enterprises, develop mixed ownership economy and cultivate world-class enterprises with global competitiveness. Under such an opportunity, urban construction \& investment company can actively promote equity diversification, realize the organic combination of financial fund and financial capital, and transform into a state-owned capital operation platform. It focuses on capital operation, enriches various financing tools, and promotes the reform of mixed ownership and the optimization and integration of the layout of state-owned enterprises.

Taking the urban construction investment companies in Tianjin, Shandong, Chongqing and other places as examples, in 2001, Tianjin taida holdings co., ltd. was integrated and established by the Tianjin technology development zone head office and other urban construction \&investment companies in the region, covering a number of fields such as banking, fund and securities. In 2005, Chongqing yufu group established and operated the strategic emerging industry equity investment fund, which enriched the capital replenishment channel for the group and solved the capital demand of the group. Shandong state-owned assets investment holdings has also established a state-owned capital operation company with the supervision mode of capital management, which has strengthened the competitiveness of enterprise in the economy, enhanced the hematopoietic ability in various 
aspects, enriched the financing channels, and provided valuable reference for the transformation of other urban construction \&investment companies.

\section{The Three Parties Will Work Together to Promote the Transformation and Development of Urban Construction \& Investment Company}

Although the transformation purpose of urban construction \& investment is to cut off the relationship with the government, if the move is too rapid and too fast to make urban construction \& investment company become self-reliant, it may also make the urban construction \& investment unable to adapt to the market environment in a short time, leading to its bankruptcy. This, in turn, exacerbates the debt problem and causes panic. Therefore, in order to make urban construction \& investment company become a profitable and self-reliant entity, the central government and local governments should also introduce corresponding supporting measures to help and promote the transformation of urban construction \& investment company and enhance its impetus and possibility of transformation.

\subsection{The Central Government Should Provide Policy Support for Transformation and Give Enterprises Transformational Period}

Since local government debts are not supervised by the same central ministry, and there is no consensus on the treatment of local government debts by several central ministries, so there is no clear definition of the standardization for the transformation of urban construction $\&$ investment company. In order to make the transformation of urban construction $\&$ investment companies has legal basis, the central government should carry out comprehensive statistics and careful selection of urban construction \& investment companies, unify the identification standards of urban construction $\&$ investment companies, and divide categories according to different types of urban construction $\&$ investment companies, different debt scales and different profitability, forming a unified opinion.

The central government should give the urban construction \& investment company a certain transformational period and further identify its debts, as there are thousands of companies and their conditions are different. At the same time, the central government should also give local governments some autonomy, such as granting urban construction \& investment company franchise rights and economic subsidy, etc.

\subsection{Local Governments Give Preferential Policies Such as Franchise Rights and Subsidy}

After the central government gives policy support, the local government should give economic policy support. The fundamental reason why the transformation of local urban construction \& investment company is difficult is that it is difficult to survive independently after being divorced from the "support" of government, and it is even more difficult to repay the debts borrowed. The resulting fear makes it even less motivated to transform, leaving it dependent on the government for support. In order to enhance the survival ability of urban construction\& investment company after its transformation and improve its motivation for transformation, local government should give economic guarantees such as franchise rights, subsidy and promotion of ownership reform, so that it can gradually become fully self-profitable and self-reliant, no longer waste public resources and reduce the local debt burden.

\subsection{The Enterprise Strengthens the Resource Integration Capability and Enhances Its Own Profitability}

Under the escort of the policy and economic support of central and local governments, urban construction \& investment company should actively seize opportunities, give proper positioning based on its current situation, and seek a way out for spontaneous transformation. Firstly, the company should have a correct understanding of its own advantages and disadvantages. Secondly, it should make a correct strategic positioning, so as to select industries suitable for itself and avoid market competition as much as possible. 
In order to further enhance profitability, a number of urban construction \& investment companies can integrate on their own. First, it can be the same or similar companies with high business relevance to integrate, centralize their advantages, enhance capital strength, and form larger enterprises. Secondly, cross-regional urban construction \& investment companies can also integrate resources to promote the coordinated development of urban agglomeration. In addition, urban construction \& investment companies should continue to absorb capital. The government can use land as capital for investment, and social capital and even foreign capital can participate in the consolidation and investment, so that a new type of state-owned enterprise can be formed and its profitability can be greatly improved.

In order to be able to operate in the market in the long run, urban construction $\&$ investment company should also carry out enterprise reform in response to internal criticism. It needs to operate autonomously and gradually reduce administrative intervention by local government. The enterprise itself should have a sound leadership team, and be responsible for all matters of the enterprise, instead of being appointed or concurrently managed by the local government, and truly be responsible for itself. It should improve the corresponding operation mechanism, eliminate bureaucracy, enhance decision-making ability, establish and improve enterprise organizational structure, actively learn management experience from benchmark enterprises in the industry, establish risk pre-warning mechanism and handling mechanism after the occurrence of risks, and make itself a real state-owned enterprise.

\section{Conclusion}

In conclusion, we know that municipal bond has gone through more than 20 years, making a lot of contributions to China's economic development, but also adding burdens and hidden dangers. Though it will be difficult to completely replace municipal bond in a short period of time, the urban construction \& investment company's mission of financing for government will come to an end sooner or later. Not only China, but also the United States and European countries are also facing the debt crisis, and the government debt problem has gradually attracted the attention of governments in various countries. In order to comprehensively manage municipal bond and reduce government debt risk, it is also necessary to learn from the successful experience of foreign countries and combine with China's actual conditions to realize the transformation of urban construction \& investment company under the premise of stabilizing market environment and government credit.

To achieve successful transformation, it is difficult for urban construction \& investment company to establish and develop in the market on its own. The central government also needs to issue relevant policies to guide the transformation of urban construction \& investment companies, so that they have a way out. Local governments also need to provide corresponding economic support and adopt policies such as granting franchise rights and tax deduction and exemption, so as to enhance the transformation confidence and capability of urban construction \& investment companies. Urban construction \& investment company should also actively explore the path of marketization transformation, learn from successful transformation experience at home and abroad, make rational use of fiscal policies and economic support, constantly improve its hematopoietic ability and profitability, and finally achieve a complete marketization transformation.

\section{Acknowledgements}

Thank for the support of National Social Science Foundation of China (Item NO. 14CJY025).

\section{References}

[1]. Ren zeping, chief economist of Evergrande group and director of Evergrande institute of economics, Deleveraging enters the deep-water zone [N]. Entrepreneur daily,2018-08-13(A03). 
[2]. Ma ling, intern journalist. Ministry of finance: 534.3 billion yuan of local government bond issued nationwide in June [N]. Financial times,2018-07-19(001).

[3]. Cleaning up local debts is a battle for full deleveraging [N]. 21st century economic report,201807-18(001).

[4]. He xiaogang. Reform of state-owned capital investment and operation company and regulatory transformation of state-owned enterprises -- cases and experience of Shandong, Chongqing and Guangdong [J]. Economic system reform,2018(02):24-27.

[5]. Chongqing commercial daily - upstream finance \& economics, Liu yong, chief reporter, Gao rui, intern Performance of Chongqing water increased by $94 \%$ last year, and sewage treatment accounted for $48 \%$ of total revenue [N]. Chongqing commercial daily,2018-03-25(004).

[6]. Li meng. Development and governance of local disguised debt behavior [J]. Tianjin social science,2018(02):115-119.

[7]. Ma jinhua, Liu rui. Historical comparative study on local government debt inflation [J]. Journal of central university of finance and economics,2018(01):3-11.

[8]. Editorial department of this magazine. Cultivating world-class enterprises [J]. Research on modern state-owned enterprises, 2017(23):32-33.

[9]. Li xiaohong. Analysis on the scale and causes of local government debt in China [D]. Zhejiang university,2017.

[10]. Li huijie. Research on credit risk and transformation development of China's local government financing platforms [D]. Central university of finance and economics,2017.

[11]. Zheng zhongliang, Wang linting, Li xiang. Research on the transformation of local financing platforms in the context of supply-side reform [J]. Macroeconomic management,2016(10):61$63+68$.

[12]. Ma yipeng. Transformation path of local government financing platforms: perspectives on water conservancy industry [J]. Reform,2015(03):82-88.

[13]. Li jingwei. Transformation and development of local financing platforms under the background of new budget law and its supporting policies and regulations [J]. Journal of central university of finance and economics,2015(02):3-9.

[14]. Opinions on strengthening the management of local government debt issued by the state council [J]. Comprehensive transportation,2014(10):94.

[15]. Zhong yuan, reporter. Ma 'anshan urban construction \& investment company first changed into Jiangdong holdings [N]. Economic information daily,2014-03-07(011).

[16]. Zhang liheng. Debt risk study of China's local government financing platforms [D]. Tianjin university of finance and economics, 2013.

[17]. He jiajia. Research on development strategy of local state-controlled platform company [J]. Reform and opening-up,2012(01):29-30. 